\title{
PENGARUH SISTEM INFORMASI KEPEGAWAIAN DAERAH DAN SISTEM PENGENDALIAN INTERNAL TERHADAP KINERJA APARATUR SIPIL NEGARA PEMERINTAH DAERAH KOTA TANGERANG PROVINSI BANTEN
}

\author{
Oleh \\ Fitdina Aprianto ${ }^{1}$, \\ Ngadisah $^{2}$, Sampara Lukman ${ }^{3}$ \\ 1) Pemerintah Kota Tangerang \\ Program Magister Terapan Studi Pemerintahan Daerah Institut Pemerintahan Dalam Negeri \\ apriantofitdina@gmail.com \\ ${ }^{2,3)}$ Institut Pemerintahan Dalam Negeri
}

\begin{abstract}
$T$ The paradigm alteration in governance, especially in regional autonomy is carried out as an effort to realize good governance. Efforts are being made to support this matter, which by implementing an employee information system and an internal control system in each SKPD. This study aims to analyze the influence of the personnel information system and internal control system on the performance of the state civil servants in Pemerintah Daerah Kota Tangerang.

This research was conducted using quantitative descriptive methods with a sample of 269 people. The data obtained were then analyzed descriptively and statistically using multiple regression analysis.

The results showed that the Personnel Information System based on descriptive analysis in this study was in the Effective category, and based on inferential analysis partially affected 60.9\% of the performance of the Civil Service State Government of the City of Tangerang, the Internal Control System based on descriptive analysis in this study was in the category Applied, and based on inferential analysis partially influences $42.7 \%$ on the performance of the Civil Apparatus of the City Government of the City of Tangerang, employee performance based on descriptive analysis in this study was in the Competent category, and based on inferential analysis of the Civil Service Information System and Internal Control System simultaneous effect of $78.5 \%$ on the performance of the civil apparatus of the City Government of the City of Tangerang.
\end{abstract}

Keywords: personnel information system, internal control systems, employee performance, good governance, state civil apparatus

\section{ABSTRAK}

$\mathrm{P}$ erubahan paradigm khususnya dalam otonomi daerah dilakukan sebagai upaya mewujudkan tata kelola pemerintahan yang baik (good governance) Upaya-upaya yang dilakukan untuk menunjang hal tersebut di antaranya adalah dengan menerapkan sistem informasi kepegawaian dan sistem pengendalian internal pada setiap SKPD. Penelitian ini bertujuan untuk menganalisis pengaruh sistem informasi kepegawaian dan sistem pengendalian internal terhadap kinerja aparatur sipil negara dan Pemerintah Daerah Kota Tangerang. 
Penelitian ini dilakukan dengan menggunakan metode deskriptif kuantitatif dengan sampel penelitian sebanyak 269 orang. Data yang diperoleh kemudian dianalisis secara deskriptif dan statistik dengan menggunakan analisis regresi berganda.

Hasil penelitian menunjukkan bahwa Sistem Informasi Kepegawaian berdasarkan analisis deskriptif dalam penelitian ini termasuk dalam kategori Efektif, dan berdasarkan analisis inferensial secara parsial berpengaruh sebesar 60,9\% terhadap kinerja Aparatur Sipil Negara Pemerintah Daerah Kota Tangerang, Sistem Pengendalian Internal berdasarkan analisis deskriptif dalam penelitian ini termasuk dalam kategori Diterapkan, dan berdasarkan analisis inferensial secara parsial berpengaruh sebesar 42,7\% terhadap kinerja Aparatur sipil Negara Pemerintah Daerah Kota Tangerang, Kinerja pegawai berdasarkan analisis deskriptif dalam penelitian ini termasuk dalam kategori Kompeten, dan berdasarkan analisis inferensial Sistem Informasi Kepegawaian dan Sistem Pengendalian Internal secara simultan berpengaruh sebesar 78,5\% terhadap kinerja Aparatur sipil Negara Pemerintah Daerah Kota Tangerang.

Kata kunci: sistem informasi kepegawaian, sistem pengendalian internal, kinerja pegawai, tata kelola pemerintahan yang baik, aparatur sipil negara

\section{PENDAHULUAN}

Penggunaan sistem informasi bagi
institusi dikatakan sebagai faktor pendukung dalam terwujudnya transparansi dan akuntabilitas pelayanan kepada publik. Dasar hukum penggunaan sistem informasi dalam lingkup pemerintahan tersebut telah diatur oleh pemerintah melalui penerbitan Panduan Pembangunan Infrastruktur Portal Pemerintah dan Panduan Manajemen Sistem Dokumen Elektronik Pemerintah, serta pembentukan Dewan Teknologi Informasi dan Komunikasi Nasional yang diatur dalam Keputusan Presiden No. 20 Tahun 2006.

Salah satu program yang memanfaatkan sistem informasiyang sedang digalakkan oleh Pemerintah Indonesia saat ini adalah Sistem Informasi Manajemen yang merupakan sebuah bidang terapan yang ditujukan pemanfaatannya bagi kegiatan pelayanan publik, baik bagi kegiatan yang dilakukan antarlembaga atau organisasi pemerintah. Menurut Keputusan Menteri Dalam Negeri No. 17 Tahun 2000, Sistem Informasi Manajemen Kepegawaian merupakan suatu totalitas terpadu yang terdiri dari perangkat pengolah meliputi pengumpulan prosedur, tenaga pengolah dan perangkat lunak, perangkat penyimpanan meliputi pusat data serta perangkat komunikasi yang saling berkaitan, saling ketergantungan dan saling menentukan dalam rangka penyediaan informasi di bidang kepegawaian.

Dasar hukum sistem informasi kepegawaian lainnya, yaitu diatur dalam Undang-Undang No. 5 Tahun 2014 tentang Aparatur Sipil Negara, Peraturan Kepala Badan Kepegawaian Negara No. 14 Tahun 2011 tentang Pedoman Pengembangan Database Pegawai Negeri Sipil.

Kota Tangerang merupakan salah satu daerah yang telah menerapkan sistem informasi kepegawaian daerah (SIKDA) yang telah terintegrasi dengan Badan Kepegawaian Nasional. Beberapa fungsi dan fitur unggulan yang ada pada SIKDA, tidak dapat dijumpai pada SIMPEG pada umumnya, sekaligus juga menjadikan SIKDA sebagai SIMPEG terbaik di antara SIMPEG milik pemerintah Kota/ Kabupaten se-Indonesia.

Permasalahan yang terjadi di lingkup pemerintah kota Tangerang berkaitan dengan SIKDA salah satunya dialami oleh Dinas Kesehatan, yaitu pada beberapa ASN yang mengajukan izin belajar, tidak semuanya memenuhi kriteria. Dari 33 ASN yang mengajukan, hanya 14 yang dapat diterbitkan izin belajarnya, sementara 19 ASN menghadapi hambatan yang terdiri dari 
ditolaknya izin belajar karena pendidikan yang ditempuh tidak linier dengan pendidikan sebelumnya, berkas tidak lengkap sejak 2017 dan belum ada tindak lanjut hingga saat ini, dan sebagian besar izin belajar tidak terbit karena belum memenuhi ketentuan bahwa perkuliahan ada pada jam kerja.

Selain itu, permasalahan lain adalah adanya ASN yang mengikuti tugas belajar namun sponsornya bukan berasal dari Kementerian, lembaga atau pemerintah, melainkan dari perusahaan yang mengakibatkan perizinan tugas belajar ASN tersebut bermasalah. Kemudian, berdasarkan pra penelitian yang dilakukan oleh peneliti ditemukan kesenjangan berupa:

1. Masih kurang optimalnya pemanfaatan SIKDA yang terlihat dari respons pegawai yang cenderung lambat dalam melakukan penginputan data.

2. Permasalahan peralihan arsip yang berasal dari arsip tercetak ke arsip digital yang memerlukan proses yang cukup panjang dan juga peralatan yang terbatas, dan juga banyaknya data yang harus diinput.

3. Permasalahan pada kinerja ASN yang berdampak pada terhambatnya pengelolaan SIKDA

4. Permasalahan yang berkaitan dengan kemampuan adaptasi para pengelola SIKDA.

Hal yang paling penting dalam pengelolaan sumber daya manusia adalah mengenai kinerja pegawai. Pengertian kinerja menurut Mangkunegara (2016:67) adalah hasil kerja secara kualitas dan kuantitas yang dicapai oleh seorang pegawai dalam melaksanakan tugasnya sesuai dengan tanggung jawab yang diberikan kepadanya.

Mangkunegara (2016:67) menyatakan bahwa faktor yang memengaruhi kinerja antara lain faktor kemampuan dan faktor motivasi. Faktor kemampuan (ability) karyawan terdiri dari kemampuan potensi pendidikan yang memadai untuk jabatannya dan terampil dalam mengerjakan pekerjaan sehari-hari, maka ia akan lebih mudah mencapai kinerja yang diharapkan. Oleh karena itu pegawai perlu ditempatkan pada pekerjaan yang sesuai dengan keahliannya (the right man in place, the man on the right job) Sementara Motivasi berbentuk dari sikap (attitude) seseorang karyawan dalam menghadapi situasi (situation) motivasi merupakan kondisi yang menggerakkan dari karyawan yang terarah untuk mencapai tujuan organisasi (tujuan kerja).

Mengenai SPI, pemerintah sendiri telah menerbitkan Peraturan Pemerintah No. 60 Tahun 2008 tentang Sistem Pengendalian Internal Pemerintah (SPIP), yang mengatur mengenai arahan tentang konsep SPIP dan cara pelaksanaannya. SPIP bertujuan untuk memberikan keyakinan yang memadai terhadap empat hal yakni: tercapainya efektivitas dan efisiensi pencapaian tujuan penyelenggaraan pemerintahan negara, keandalan pelaporan keuangan, pengamanan aset negara dan ketaatan terhadap peraturan perundang-undangan.

Sistem Pengendalian Intern Pemerintah dilaksanakan oleh Badan Pengawasan Keuangan dan Pembangunan (BPKP) dan Inspektorat melalui aparat Pengawasan Intern Pemerintah. Pemerintah Kota Tangerang, sebagai bagian dari Pemerintah Negara Republik Indonesia, turut serta menerapkan sistem Pengendalian Intern Pemerintah dalam penyelenggaraan kegiatan-kegiatan pemerintahan yang dilaksanakan.

Sistem Pengendalian Internal di Dinas Kesehatan Kota Tangerang berdasarkan pra penelitian menunjukkan pencapaian efektivitas yang meningkat, yaitu dengan selalu dilakukannya evaluasi dalam rangka meningkatkan fungsi SPI melalui:

1. Memberi rekomendasi kepada pimpinan mengenai perbaikan dan berbagai sistem 
dan prosedur dalam proses pelaksanaan pengawasan

2. Memberi rekomendasi mengenai upaya peningkatan efisiensi dan efektivitas melalui penilaian pencapaian pekerjaan

3. Membantu menciptakan dan memastikan SPI telah dipatuhi dan sesuai dengan ketentuan yang berlaku.

Permasalahan terkait SPI di Dinas Kesehatan Pemerintah kota Tangerang salah satunya adalah bahwa apabila terdapat pelanggaran terhadap peraturan yang berlaku, sanksinya belum sepenuhnya dapat diterapkan. Seperti yang terjadi pada penerbitan surat izin belajar yang terhambat karena berbagai hal terutama karena ketidaklengkapan data atau berkas dari ASN yang bersangkutan, sanksi yang diberikan hanya berupa teguran saja dan itu pun berupa pengingat dalam kolom komentar pada SIKDA ASN yang bersangkutan.

\section{Rumusan Masalah}

1. Seberapa besar pengaruh sistem informasi kepegawaian terhadap kinerja aparatur sipil negara Pemerintah Daerah Kota Tangerang?

2. Seberapa besar pengaruh sistem pengendalian internal terhadap kinerja aparatur sipil negara Pemerintah Daerah Kota Tangerang?

3. Seberapa besar pengaruh sistem informasi kepegawaian dan sistem pengendalian internal terhadap kinerja aparatur sipil negara dan Pemerintah Daerah Kota Tangerang?

\section{KONSEP TEORETIS}

Sistem informasi kepegawaian merupakan salah satu dampak dari perkembangan teknologi informasi yang diterapkan dalam sistem pemerintahan guna menunjang kepada terwujudnya tata kelola pemerintahan yang baik. Dalam penerapannya terdapat berbagai keterbatasan. Dalam pencapaian efektivitas sistem informasi kepegawaian, pemerintah harus memiliki sumber daya manusia yang berkompeten dan sistem pengawasan atau pengendalian internal yang baik. Teori yang digunakan sebagai Grand Theory dalam penelitian ini adalah Technology Acceptance Model (TAM) yang dikembangkan oleh Davis et al. (1989) yang menjelaskan bahwa konstruk utama dari teori ini adalah kegunaan dari teknologi yang didefinisikan sebagai sejauh mana seseorang percaya bahwa dengan menggunakan suatu teknologi akan meningkatkan kinerja pekerjaannya (Hartono, 2008: 114) Dengan berdasarkan pada teori tersebut, peneliti ingin mengungkapkan sejauh mana pegawai merasa terbantu dengan adanya sistem informasi kepegawaian dan bagaimana efektivitas sistem tersebut.

Middle Theory yang digunakan dalam penelitian ini adalah teori kognitif sosial yang menyatakan bahwa pengaruh lingkungan sosial, kognitif dan faktor personel lainnya dapat saling memengaruhi. Pengaruh lingkungan sosial berupa dorongan orang lain baik secara individual maupun organisasional dalam rangka perwujudan sistem pengendalian internal dinilai akan memengaruhi efektivitas penggunaan sistem informasi kepegawaian. Selain itu dukungan dari lingkungan juga dinilai akan berpengaruh terhadap kinerja sumber daya manusia karena lingkungan akan memengaruhi keinginan untuk mengembangkan diri dan meningkatkan kemampuan diri dari seseorang.

Applied Theory yang digunakan dalam penelitian ini adalah teori efektivitas sistem informasi yang dikemukakan oleh DeLone dan McLean yang dikutip dari Jogiyanto (2007:14) yang menyebutkan bahwa efektivitas sistem informasi dapat diukur melalui kualitas sistem, kualitas informasi, kualitas pelayanan, penggunaan sistem, kepuasan pengguna dan manfaat bersih. Sementara untuk mengukur kinerja pegawai, 
diukur dengan menggunakan indikator yang dikemukakan oleh Bernardin dan Russel (2008: 239), yaitu Kuantitas Kerja, Kualitas Kerja, Pengetahuan Pekerjaan, Kerja sama, Dapat Diandalkan, Kreativitas, Inisiatif dan Kualitas pribadi. Sistem pengendalian internal dalam penelitian ini diukur melalui lingkungan pengendalian, penilaian risiko, aktivitas pengendalian, informasi dan komunikasi, serta pemantauan yang merupakan penjelasan indikator sistem pengendalian internal menurut Alvin A. Arens (2014:345).

Pengukuran sistem informasi kepegawaian daerah dalam penelitian ini didasarkan pada pengukuran efektivitasnya, Menurut DeLone dan McLean yang dikutip dari Jogiyanto (2007:14) cara pengukuran efektivitas sistem informasi adalah sebagai berikut.

1. Sistem quality (kualitas sistem)

2. Information quality (kualitas informasi)

3. Service quality (kualitas pelayanan)

4. Sistem use (penggunaan sistem)

5. User satisfaction (kepuasan pengguna)

6. Net benefits (manfaat bersih)

Sementara untuk mengukur sistem pengendalian internal didasarkan pada pendapat Arens (2014: 345) yang menyebutkan bahwa unsur Sistem Pengendalian Internal pemerintah antara lain sebagai berikut.

1. Lingkungan Pengendalian

2. Penilaian risiko

3. Kegiatan Pengendalian

4. Informasi dan Komunikasi

5. Pemantauan Sistem Pengendalian Internal

Untuk mengukur kinerja pegawai, dapat dilakukan dengan menentukan standar pekerjaan yang dapat diukur dan dipahami secara jelas. Pengukuran kinerja dapat didasarkan pada dimensi-dimensi yang menurut Bernardin dan Russel (2008: 239) tediri dari quantity of work, quality of work, job knowledge, creativeness, cooperation, dependability, initiative, dan personel qualities.

\section{METODE PENELITIAN}

Penelitian ini dilakukan dengan menggunakan metode tipe deskriptif yang dimaksudkan untuk memberikan gambaran secara jelas mengenai masalah yang diteliti, menginterpretasikan serta menjelaskan data secara sistematis. Pendekatan yang dilakukan bersifat kuantitatif yang menurut Sugiyono (2014: 34) adalah metode yang berlandaskan pada filsafat positivisme, digunakan untuk meneliti populasi atau sampel tertentu yang kemudian dilakukan pengujian untuk menguji hipotesis yang telah ditetapkan.

Populasi dalam penelitian ini adalah pegawai yang berada di Dinas Kesehatan Pemerintah Daerah Kota Tangerang yang berjumlah 815 orang. Sementara sampel yang digunakan dalam penelitian ini adalah sebanyak 269 orang pegawai Dinas Kesehatan Pemerintah Daerah Kota Tangerang. Sampel tersebut kemudian ditentukan secara berstrata yang membagi populasi ke dalam kelompok berdasarkan SKPD yang ada dengan jenis sampel strata proporsional.

\section{HASIL DAN PEMBAHASAN}

\section{Pengaruh Sistem Informasi Kepegawaian terhadap Kinerja Aparatur Sipil Negara Pemerintah Daerah Kota Tangerang}

Berdasarkan hasil analisis inferensial, didapat hasil bahwa sistem informasi kepegawaian memiliki pengaruh sebesar $60,9 \%$ terhadap kinerja pegawai sedangkan sisanya dipengaruhi oleh faktor lain. Hal ini menunjukkan bahwa sistem informasi kepegawaian berpengaruh cukup besar terhadap kinerja pegawai. 
Berdasarkan hasil analisis deskriptif, pada indikator kualitas sistem didapat hasil persentase yang cukup besar, yaitu rata-rata $80 \%$, hal ini menunjukkan bahwa kualitas sistem menurut responden dapat dimanfaatkan dengan baik. Kualitas sistem berarti kualitas dari kombinasi perangkat keras dan perangkat lunak dalam sistem informasi, jika pengguna sistem informasi kepegawaian merasakan kemudahan dalam menggunakan sistem tersebut, juga dapat diandalkan dan kecanggihannya dapat membantu mereka dalam melakukan pekerjaannya, maka kualitas sistem informasi kepegawaian tersebut sudah baik dan dapat diandalkan sehingga pengguna akan lebih banyak waktu untuk mengerjakan hal lain yang kemungkinan akan meningkatkan kinerja mereka secara keseluruhan.

Berdasarkan analisis deskriptif, bahwa kualitas informasi juga memiliki persentase yang cukup besar yang menunjukkan bahwa informasi yang didapat dari sistem informasi kepegawaian mudah dimengerti, akurat, lengkap dan waktu yang efisien sehingga dapat mendukung dalam pengambilan keputusan yang efektif yang pada akhirnya akan memengaruhi kepada kinerja baik secara individual maupun kinerja satuan kerja perangkat daerah yang bersangkutan.

Berdasarkan hasil analisis deskriptif, kualitas pelayanan dari sistem informasi kepegawaian juga memiliki persentase yang cukup besar, yang menunjukkan bahwa sistem informasi kepegawaian selalu terbaharuinya sistem dan adanya jaminan keamanan data serta kemudahan dalam pengoperasiannya sehingga sistem informasi kepegawaian mampu bertahan dan mendapat kepercayaan dari penggunanya.

Berdasarkan hasil analisis deskriptif, didapat hasil bahwa sistem informasi kepegawaian digunakan oleh seluruh pegawai dan mereka mampu menggunakannya secara maksimal. Meskipun terdapat beberapa orang yang belum mampu menggunakannya karena berbagai faktor, namun penggunaan sistem yang mudah terbukti dapat memengaruhi kinerja para pegawai di satuan kerja perangkat daerah menjadi lebih baik.

Berdasarkan analisis deskriptif, kepuasan pengguna memiliki persentase yang cukup, hal ini menunjukkan bahwa tingkat kepentingan dan harapan pengguna harus disesuaikan. Konsep kepuasan pengguna menjadi hal yang penting agar pengguna tetap memanfaatkan sistem informasi kepegawaian secara maksimal sehingga dapat mendukung kepada meningkatnya kinerja.

Berdasarkan hasil analisis deskriptif, diketahui bahwa manfaat bersih memiliki persentase yang cukup besar, di mana menunjukkan bahwa pengguna merasakan sistem informasi kepegawaian dapat mendukung kinerja mereka dan dapat menambah pengetahuan bagi mereka. Manfaat bersih mengacu kepada dampak yang timbul dari pemakaian sistem informasi kepegawaian, termasuk dampak terhadap individu pegawai, dampak terhadap masyarakat, dan dampak terhadap organisasi. Dengan dapat dirasakannya manfaat-manfaat bersih dari sistem informasi kepegawaian, diharapkan dapat memengaruhi terhadap peningkatan efisiensi dan efektivitas pengambilan keputusan, peningkatan produktivitas kerja, kesejahteraan pengguna, dan pada akhirnya peningkatan kinerja baik individu maupun satuan kerja perangkat daerah.

\section{Pengaruh Sistem Pengendalian Internal terhadap Kinerja Aparatur Sipil Negara Pemerintah Daerah Kota Tangerang}

Berdasarkan hasil analisis inferensial secara parsial didapat hasil bahwa sistem pengendalian internal memiliki pengaruh sebesar 42,7\% terhadap kinerja pegawai sedangkan sisanya dipengaruhi oleh faktor lain. Temuan penelitian ini menunjukkan bahwa dalam pelaksanaan tugas sehari-hari 
di Dinas Kesehatan Kota Tangerang secara umum telah memahami kelima unsur dari sistem pengendalian internal.

Pelaksanaan kegiatan yang didasari oleh sistem pengendalian yang baik diharapkan tidak saja dapat menciptakan tata kelola pemerintahan yang baik, namun juga dapat mewujudkan kualitas kinerja yang baik pada setiap satuan kerja perangkat daerah. Penerapan sistem pengendalian internal di Kota Tangerang didukung oleh komitmen penegakan etika dan integritas yang dilakukan oleh pimpinan yang berimbas pada terciptanya lingkungan kerja yang kondusif.

Berdasarkan analisis deskriptif, lingkungan pengendalian memiliki skor aktual di atas $75 \%$ pada setiap indikatornya, hal ini membuktikan bahwa lingkungan pengendalian yang baik memberikan pengaruh positif terhadap peningkatan kinerja satuan kerja perangkat daerah. Terciptanya lingkungan kerja yang kondusif dari setiap pimpinan akan membawa suasana yang nyaman bagi setiap pegawai untuk bekerja dengan baik sesuai dengan tujuan dan fungsinya sebagai aparatur sipil negara.

Berdasarkan analisis deskriptif pada indikator penilaian risiko, kedua indikator juga menunjukkan hasil di atas 79\% yang membuktikan bahwa penilaian risiko berpengaruh positif terhadap kinerja pegawai. Arahan yang spesifik atas tugas dan fungsi setiap bidang pekerjaan akan sangat berpengaruh pada pelaksanaan kegiatan setiap pegawai. Dengan dijaganya efisiensi operasional dan kesesuaian pelaksanaan dengan kebijakan manajemen serta evaluasi rutin terhadap pelaksanaan kegiatan tentu berkaitan erat dengan kemampuan pengelolaan risiko. Diterapkannya penilaian dan analisis risiko yang baik dan akurat diharapkan dapat mencegah penyimpangan karena dapat meminimalkan risiko yang terjadi dalam setiap pelaksanaan pekerjaan, dan juga dapat membantu manajemen dalam menyiapkan tindakan pengendalian yang harus diambil jika terjadi penyimpangan.

Penilaian risiko diawali dengan penetapan maksud dan tujuan instansi pemerintah yang jelas dan konsisten baik pada tingkat instansi maupun tingkat kegiatan. Kemudian mengidentifikasi secara efisien dan efektif risiko yang dapat menghambat pencapaian tujuan tersebut, baik yang bersumber dari dalam maupun dari luar instansi. terhadap risiko yang telah diidentifikasi, dianalisis untuk mengetahui pengaruhnya terhadap pencapaian tujuan. Pimpinan instansi pemerintah merumuskan pendekatan manajemen risiko dan kegiatan pengendalian risiko yang diperlukan untuk memperkecil risiko.

Berdasarkan analisis deskriptif, dapat diketahui bahwa pada indikator aktivitas pengendalian juga memiliki persentase di atas $75 \%$ di mana hal tersebut menunjukkan bahwa aktivitas pengendalian memiliki pengaruh positif terhadap kinerja pegawai. Aktivitas pengendalian pada umumnya berhubungan dengan kebijakan dan prosedur yang berkaitan dengan pelaksanaan kegiatan yang dilakukan oleh pegawai. Adanya review atas kegiatan yang berkaitan dengan kinerja pegawai perlu dilakukan untuk meninjau kinerja satuan kerja perangkat daerah secara keseluruhan.

Selain itu, pengendalian atas pengelolaan sistem informasi juga dibutuhkan oleh setiap satuan kerja perangkat daerah sehingga informasi-informasi yang sifatnya rahasia tidak mudah bocor terutama kepada publik. Dengan demikian, otorisasi, terutama terhadap setiap transaksi, menjadi suatu keharusan dilakukannya pengendalian agar mengurangi terjadinya kemungkinan penyimpangan. Aktivitas pengendalian yang baik diharapkan akan membantu manajemen dalam mencapai misi dan tujuan organisasi.

Berdasarkan hasil analisis deskriptif terhadapindikatorinformasidankomunikasi, 
terdapat persentase yang terbilang cukup rendah, yaitu pada indikator terdapat sarana informasi yang dapat dimanfaatkan dengan baik. Hal ini menunjukkan bahwa sebagian besar responden menyatakan kurang setuju atas pernyataan tersebut, yang membuktikan adanya kekurangan pada sarana informasi yang berkaitan dengan sistem pengendalian internal. Tersedianya berbagai bentuk sarana komunikasi sangat diperlukan dan harus dapat dimanfaatkan dengan baik, karena setiap informasi harus secara konstan dikelola dan dikomunikasikan dengan baik dan juga harus diperbaharui secara berkala agar jalur komunikasi tetap lancar dan menunjang kepada terlaksananya kegiatan satuan kerja perangkat daerah dengan baik.

Berdasarkan hasil analisis deskriptif, indikator pada dimensi pemantauan menunjukkan hasil di atas $70 \%$ yang menunjukkan bahwa pemantauan terlaksana dengan baik. Pemantauan yang berkelanjutan serta adanya evaluasi sangat berguna untuk menunjukkan respons satuan kerja perangkat daerah terhadap penilaian kinerja oleh auditor. Diharapkan dengan adanya pemantauan ini akan tersusun laporan hasil pemantauan untuk menjadi acuan bagi aparat pengawas intern ketika melaksanakan tindak lanjut terhadap hasil penilaian kinerja.

\section{Pengaruh Sistem Informasi Kepegawaian danSistemPengendalian Internal terhadap Kinerja Aparatur Sipil Negara dan Pemerintah Daerah Kota Tangerang}

Berdasarkan hasil analisis inferensial, diketahui bahwa besarnya pengaruh sistem informasi kepegawaian dan sistem pengendalian internal terhadap kinerja pegawai adalah sebesar 78,5\% sedangkan sisanya dipengaruhi oleh faktor lain. Selain itu, berdasarkan uji hipotesis berdasarkan tabel tersebut, dapat diketahui juga dengan melihat hasil tabel coefficient pada uji $\mathrm{t}$ dengan membandingkan nilai $t_{\text {hitung }}$ dengan $\mathrm{t}_{\text {tabel }}$ didapat hasil bahwa besarnya nilai $\mathrm{t}_{\text {hitung }}=$ 6,586 , yang berarti lebih besar dari $t_{\text {tabel }}$ yang bernilai 2,0003 (dengan signifikansi 0,05 dan derajat kebebasan 62-2 $=60$ ) sedangkan besarnya signifikansi 0,000 lebih kecil dari 0,05 . Dengan demikian $\mathrm{H}_{0}$ ditolak yang berarti ada pengaruh antara sistem informasi kepegawaian dan sistem pengendalian internal terhadap kinerja pegawai.

Pencapaian tata kelola pemerintahan yang baik tersebut salah satunya dapat dicapai dengan penggunaan sistem informasi atau teknologi informasi. Perkembangan teknologi informasi yang merupakan salah satu pengaruh dari globalisasi telah memberikan solusi untuk mempermudah akses birokrasi agar lebih efektif dan efisien. Penggunaan sistem informasi bagi institusi pemerintahan dapat dikatakan sebagai faktor pendukung dalam terwujudnya transparansi dan akuntabilitas pelayanan kepada publik.

Secara umum sistem informasi kepegawaian dapat meningkatkan kualitas sumber daya manusia dengan menyediakan informasi yang akurat dan efisien, sehingga pengambilan keputusan dapat dilakukan secaraobjektif.Sisteminformasikepegawaian Kota Tangerang saat ini mencakup sistem informasi terpadu yang meliputi pendataan pegawai, pengolahan data, prosedur, tata kerja, sumber daya manusia dan teknologi informasi yang cepat, lengkap dan akurat dalam rangka mendukung tertatanya administrasi kepegawaian.

Sistem informasi kepegawaian merupakan implementasi e-government dalam pelayanan di bidang kepegawaian secara transparan dan objektif. Tujuan utama sistem informasi kepegawaian ini adalah untuk membantu proses manajemen, yang dimaksudkan untuk mengefisienkan dan mengoptimalkan manajemen aparatur sipil negara di lingkungan pemerintah daerah melalui sistem basis data yang terintegrasi, tertib, teratur, transparan dan aman. 
Pengendalian internal yang memadai akan membuat kinerja pegawai menjadi baik. Hal ini sejalan dengan tujuan dari pengendalian internal, yaitu untuk memberikan keyakinan yang memadai tentang pencapaian tujuan satuan kerja perangkat daerah dan kepatuhan terhadap peraturan perundang-undangan yang berlaku.

Teori sistem menyatakan bahwa sistem terdiri dari bagian-bagian yang Bersamasama beroperasi untuk mencapai berbagai tujuan. Adanya tujuan berarti ada kinerja yang dilakukan untuk mencapainya, hal tersebut dinyatakan dalam konsep kinerja yang merujuk pada keberhasilan dalam melaksanakan tugas dan kemampuan untuk mencapai tujuan yang telah ditetapkan.

Kegiatan pengendalian internal terdiri dari penilaian terhadap kinerja dari satuan kerja perangkat daerah yang bersangkutan yang dinilai mampu membenahi kinerja pemerintah melalui terlaksananya kegiatankegiatan yang teratur. Dengan demikian akan memberikan keyakinan bagi pemerintah bahwa seluruh proses kegiatan telah berjalan sesuai dengan tolak ukur yang telah ditetapkan secara efektif dan efisien, yang pada akhirnya akan berpengaruh positif terhadap kinerja instansi pemerintah.

$\begin{array}{rcc}\text { Sebagai } & \text { organisasi } & \text { sektor publik } \\ \text { pemerintah } & \text { daerah } & \text { dituntut agar }\end{array}$ memiliki kinerja yang berorientasi pada kepentingan masyarakat dan mendorong pemerintah untuk senantiasa tanggap dengan lingkungannya, dengan berupaya memberikan pelayanan terbaik secara transparan dan berkualitas serta adanya pembagian tugas yang baik pada pemerintah tersebut. Tuntutan yang semakin tinggi diajukan terhadap pertanggungjawaban yang diberikan oleh penyelenggara negara atas kepercayaan yang diamanatkan kepada mereka. Kinerja sektor publik sebagian besar dipengaruhi oleh kinerja aparat atau manajerial. Unit-unit kerja organisasi publik diharapkan dapat menciptakan lingkungan kerja yang kondusif dengan menginteraksikan kemampuan pimpinan dan kemampuan bawahan

Dengan diterapkannya sistem pengendalian internal yang efektif di Kota Tangerang, diharapkan dapat mendorong para aparatur sipil negara untuk melakukan praktik-praktik yang sehat dan akan berdampakpada peningkatan kinerja seluruh satuan kerja perangkat daerah sehingga membawa dampak positif bagi kehidupan seluruh masyarakat Kota Tangerang.

\section{SIMPULAN}

1. Sistem Informasi Kepegawaian berdasarkan analisis deskriptif dalam penelitian ini termasuk dalam kategori efektif, dan berdasarkan analisis inferensial secara parsial berpengaruh signifikan sebesar 0,003 terhadap kinerja Aparatur Sipil Negara Pemerintah Daerah Kota Tangerang

2. Sistem Pengendalian Internal berdasarkan analisis deskriptif dalam penelitian ini termasuk dalam kategori diterapkan, dan berdasarkan analisis inferensial secara parsial berpengaruh signifikan sebesar 0,002 terhadap kinerja Aparatur sipil Negara Pemerintah Daerah Kota Tangerang

3. Kinerja pegawai berdasarkan analisis deskriptif dalam penelitian ini termasuk dalam kategori kompeten, dan berdasarkan analisis inferensial Sistem Informasi Kepegawaian dan Sistem Pengendalian Internal secara simultan berpengaruh signifikan sebesar 0,000 terhadap kinerja Aparatur sipil Negara Pemerintah Daerah Kota Tangerang. 


\section{SARAN}

1. Bagi pimpinan satuan kerja pemerintahan daerah dan pihak yang terkait diharapkan dapat mengoptimalkan penggunaan sistem informasi kepegawaian agar dalam menyelesaikan kegiatan dapat sesuai dengan target. Selain itu perlu adanya penekanan tanggung jawab kepada setiap pegawai yang belum dapat memanfaatkan sistem informasi kepegawaian agar dapatmemaksimalkan waktu dan kemampuannya sehingga dapat mendukung kepada kinerja satuan kerja perangkat daerah dan tidak menghambat pelaksanaan kegiatan bidang lainnya agar pencapaian target dan tujuan organisasi dapat dilaksanakan dengan efektif dan efisien.

2. Dengan telah diterapkannya sistem pengendalian internal, diharapkan agar setiap satuan kerja perangkat daerah dapat mempertahankan dan meningkatkan kualitas pengendalian internal sehingga dapat meningkatkan kinerja aparatur sipil negara

3. Dengan adanya penelitian ini diharapkan dapat menjadi acuan bagi pihak terkait baik pihak akademisi maupun pihak teknis terkait dalam penciptaan dan pengembangan inovasi yang berkaitan dengan upaya peningkatan kinerja satuan kerja perangkat daerah terutama kinerja aparatur sipil negara.

\section{DAFTAR PUSTAKA}

Abidin, Fudin Zainal. 2014. Pengaruh Disiplin terhadap Kinerja Karyawan Pada PT. Rekatama Putra Gegana Bandung. Bandung: Universitas Winaya Mukti

Almustofa, Resa. 2014. Pengaruh Lingkungan Kerja, Motivasi Kerja, Disiplin Kerja terhadap Kinerja Pegawai (Studi Pada Pegawai Perum Bulog Divisi Regional Jakarta. Semarang: Universitas Diponegoro.

Azis, Nur Jannah Abdi. 2018. Pengaruh Sistem Pengendalian Intern Pemerintah, Sistem Informasi Manajemen Daerah dan Kualitas Sumber Daya Manusia terhadap Kinerja Manajerial Aparatur Pemerintah Daerah

Bangun, Wilson. 2012. Manajemen Sumber Daya Manusia. Bandung: Erlangga.

Basri, Seta.2011. Pengantar Ilmu Politik. Yogyakarta: Inside Book Center.

Bernardin, H. John dan Joyce, E. A. Russel. 2008. Manajemen Sumber Daya Manusia. Diterjemahkan oleh Bambang Sukoco. Bandung: Armico.

Boynton, William C., Raymond N. Johnson., 2006, Modern Auditing, 8 th Edition, New York: John Willey \& Sons Inc.

Danang Sunyoto. 2012. Manajemen Sumber Daya Manusia. Yogyakarta: CAPS.

Davis, f. D. 1989. Perceived Usefulness, Perceived Ease of Use, and User Acceptance of Information Technology. MIS Quarterly. Vol. 13 No. 5: pp319-339.

Edy Sutrisno. 2009. Manajemen Sumber Daya Manusia, Jakarta: Kencana Prenada Media Group

Erpurini, Wala. 2019. Pengaruh Sistem Informasi Manajemen Kepegawaian (Simpeg) dan Lingkungan Kerja terhadap Kinerja Karyawan pada Instalasi Narkotika, Psikotropika dan Zat Adiktif (Napza) Rumah Sakit Jiwa Provinsi Jawa Barat

Gelinas, Jr. Ulric J., Dull, richard B. 2010. Accounting Information System, 8th Edition. South Western Cengange Learning

Ghozali, Imam. 2005. Aplikasi Analisis Multivariate dengan SPSS. Semarang: Badan Penerbit Undip 
Gujarati, Damodar N. and Dawn C. Porter. 2012. Dasar-dasar Ekonometrika. Jakarta: Salemba Empat

Hartono, Jogiyanto. 2008. Teori Portofolio dan Analisis Investasi. Yogyakarta: BPFE

Hasibuan, Malayu S. P. 2009. Manajemen: Dasar, Pengertian, dan Masalah. Edisi Revisi. Jakarta: Bumi Aksara

Hasibuan, Malayu, S. P. 2007. Manajemen Sumber Daya Manusia. Jakarta: Cetakan 9. PT. Bumi Aksara

Horngren, Charles T, Walter T. Harrison dan Linda Smith Bamber. 2006. Akuntansi Edisi ke enam. Jakarta: PT Indeks Kelompok Gramedia

James, A. Hall, 2007. Sistem Informasi Akuntansi. Edisi Ketiga, Terjemahan. Amir Abadi Yusuf. Jakarta: Salemba Empat

Jogiyanto. 2007. Analisis dan Desain Sistem. Yogyakarta: Andi Offset.

Keputusan Kepala Badan Kepegawaian Negara No. 46A Tahun 2003 tentang Pedoman Penyusunan Standar Kompetensi Jabatan Struktural Pegawai Negeri Sipil

Keputusan Menteri Dalam Negeri No. 17 Tahun 2000 tentang Sistem Informasi Kepegawaian

Keputusan Presiden No. 20 Tahun 2006 Tentang. Dewan Teknologi Informasi dan Komunikasi Nasional

Mangkunegara, A. A. Anwar Prabu. 2006. Evaluasi Kinerja Sumber Daya Manusia. Jakarta: Refika Aditama.

Mardiasmo. 2012. Akuntansi Sektor Publik. Yogyakarta: Andi

Narmodo, Hernowo. dan Wajdi, M. Farid. 2008. Pengaruh Motivasi dan Disiplin terhadap Kinerja Pegawai Badan Kepegawaian Daerah Kabupaten Wonogiri. Jurnal Daya Saing Vol. 1. Surakarta: Universitas Muhammadiyah Semarang.
Peraturan Kepala Badan Kepegawaian Negara No. 14 Tahun 2011 tentang Pedoman Pengembangan Database Pegawai Negeri Sipil.

Peraturan Kepala Badan Kepegawaian Negara No. 8 Tahun 2013 tentang Perumusan Standar Kompetensi Teknis Pegawai Negeri Sipil

Peraturan Pemerintah No. 60 Tahun 2008 tentang Sistem Pengendalian Internal Pemerintah (SPIP)

Rakhmat, Jalaludin, 2009. Psikologi Komunikasi, Bandung: PT. Remaja. Rosdakarya

Ralph, Stair, M., George W. Reynolds. 2010. Principles of Information Systems: $A$ Managerial Approach. (9th edition) Australia: Thomson Course Technology

Sedarmayanti. 2011. Manajemen Sumber Daya Manusia, Reformasi Birokrasi dan. Manajemen Pegawai Negeri Sipil (cetakan kelima) Jakarta: Mekar Jaya

Sondang P. Siagian. 2011. Manajemen Sumber Daya Manusia. Jakarta: Bumi Aksara. Jakarta

Sugiyono. 2013. Metodelogi Penelitian Kuantitatif, Kualitatif dan R\&D. Bandung: ALFABETA.

Sugiyono. 2014. Metode Penelitian Kuantitatif, Kualitatif, dan R\&D. Bandung: Penerbit Alfabeta

Tangkilisan, Hessel Nogi S. 2013. Manajemen Publik. Jakarta: Grasindo

Trihapsoro, Argo. 2015. Pengaruh Kualitas Sumber Daya Manusia, Pemanfaatan Teknologi Informasi dan Sistem Pengendalian Intern Pemerintah terhadap Kinerja Pemerintah Daerah (Studi Pada Satuan Kerja Perangkat Daerah Kabupaten Boyolali)

\section{Peraturan Perundang-Undangan}

Undang-Undang No. 33 Tahun 2004 tentang Perimbangan Keuangan antara 
Visioner a Vol. $12 \backslash$ No.4\ Desember 2020: 663-674

Pemerintah Pusat dan Pemerintah Yulistiawan,Dera. 2018. Pengaruh Sistem Informasi Daerah Manajemen Kepegawaian (Simpeg) terhadap Kinerja Pegawai Sub Bagian Tata Usaha dan Kepegawaian Biro Umum Sekretariat Daerah Provinsi Jawa Barat Aparatur Sipil Negara, 